\title{
1 BOUGAINVILLE FROM CRISIS TO PEACE
}

\section{Peter Ninnes}

Nations in the Southwest Pacific have experienced a number of armed conflicts and episodes of civil unrest in the last two decades. These have included the secessionist war on Bougainville, Papua New Guinea (1988-98), the 'ethnic tension' in Solomon Islands (19982003), the three coups in Fiji, the ongoing secessionist movement in Papua, and the occupation and liberation of East Timor (1975-99). In each of these conflicts, grassroots non-government organisations (NGOs) have appeared and attempted to prevent or overcome violence and ameliorate its effects. When government services and control have broken down, or when international NGOs are uninterested or unable to help, grassroots NGOs provide important humanitarian, educational and advocacy services. Yet the crucial role played by grassroots NGOs in conflict and post-conflict recovery in the Southwest Pacific has not been well documented. The aim of this book is to document and analyse the work of one longstanding grassroots non-government organisation based in Bougainville. This NGO, the Leitana Nehan Women's Development Agency (LNWDA or Leitana Nehan), provides many salutary lessons for grassroots NGOs undertaking peace-making and peace-building work. In the 13 years of its existence, it has contributed humanitarian assistance, provided formal and non-formal education programs on peace, gender and development, become a powerful advocate at all levels of society, and expanded its work through strategic partnerships with a host of local, national and international organisations. Its work has been recognised through the award of a UN Millennium Peace Prize in 
2000 and a Pacific Peace Prize in 2004. This book makes a unique contribution to understanding the role of non-government organisations in promoting peace, gender and development in the Southwest Pacific by recording the story of the Leitana Nehan Women's Development Agency and analysing how it has managed to be successful both during times of conflict and during times of peace. This book shows how the organisation has adapted to changing circumstances in Bougainville, how it has developed and expanded its operations and the impact of these changes on its ability to recruit supporters and partners. The book also analyses the organisation's work in light of contemporary thinking about successful NGOs and effective peace-making and peacebuilding processes, drawing conclusions relevant to other NGOs undertaking peace and post-conflict recovery work.

The province of Bougainville is politically a part of Papua New Guinea. As a result of the peace process, it has recently gained a high degree of political autonomy. Geographically and culturally, it is part of Solomon Islands (Kabutaulaka 1994), although there are also prehistoric connections to parts of Papua New Guinea (Spriggs 1992). The province comprises the large islands of Bougainville and Buka, a number of small adjacent islands, and the more remote atolls of Nissan, Caterets, Mortlock, Tasman and Fead. Much of Bougainville Island is mountainous, with the highest peaks rising to over 2,000 metres (Oliver 1991), and contains many large rivers, while the southern half of the island has extensive areas of coastal swampland. The climate is tropical, with high annual rainfall.

Archaeological records indicate that Buka has been occupied by humans for at least 28,000 years, with at least one notable further wave of migration occurring 4,000 years ago (Spriggs 1992). Local foundation stories describe the actions of various ancestor figures who created human beings, features of the landscape, cultural and social practices, and various food and artefacts (see for example Blackwood 1979; Oliver 1955).

Bougainville is home to more than twenty languages-members of the Austronesian and Papuan language groups. Tok Pisin, the lingua franca of Papua New Guinea, is widely spoken, and English is used as the medium of instruction in all but the earliest years of formal 
schooling. With the exception of Nissan and Buin, Bougainville societies are matrilineal (Garasu 2002). Thus women in pre-contact times had high social status and a substantial say in community issues, including land use, and land was inherited through the mother's line. Matrilineal systems were disrupted by colonial practices and by the war in Bougainville (Wesley-Smith and Ogan 1992), but they have nevertheless survived.

Ogan (1999) argues that the impact made on Bougainvilleans by European contact, colonialism, the post-colonial era and the Bougainville crisis was varied. Many males from the north of Bougainville Island and from Buka had first contact with Europeans as a result of being recruited as labourers for plantations in Samoa, New Britain, Queensland and Fiji (Oliver 1991). Britain and Germany agreed in 1886 that Bougainville and Buka were part of the sphere of German influence, and they became an official German colony in 1899 (Bennett 2000; Oliver 1991). The Catholic Society of Mary (that is, Marists) established a mission on Bougainville in 1902, followed by a German colonial administration post at Kieta in 1905 (Bennett 2000; Oliver 1991). Plantations began to be established along the coast-resulting in the alienation of landand the main economic activity of the German colony was copra production. When World War I commenced, the German forces on Bougainville surrendered to an Australian contingent (Bennett 2000), and, after the war, Bougainville, along with other parts of German New Guinea, became a Mandated Territory administered by Australia (Oliver 1991). Wesley-Smith and Ogan (1992) argue that from 1899 up until World War II, Bougainville experienced 'classic colonialism' in which natural resources and labour were exploited, few government services were offered to local people, and missions and planters had more contact with the local population than did government officials.

The Japanese occupied Bougainville from 1942 until the Allies invaded in 1944 (Oliver 1991), exposing Bougainvilleans to the contrasting styles of Americans and Australians. After the war, the contrast between the Australian governments promises and its delivery of government services was just as stark (Wesley-Smith and Ogan 1992). In the two decades following World War II, the Australian 
government embarked on an era of 'development' in its northern colony, attempting in particular to draw more of Bougainville's population into cash cropping. Bougainvilleans, however, were reluctant to work on plantations, and much labour was brought in from other parts of Papua and New Guinea (Wesley-Smith and Ogan 1992).

The major 'development' event in Bougainville, in terms of social, cultural, economic and political impact, was the establishment of the Panguna copper mine and its associated facilities in the mountains of central Bougainville Island during the last decade of Australian colonial control. According to Oliver (1991), a number of factors combined to make possible the mining of this massive but low-grade deposit: new technology, world demand for copper, entrepreneurial flair, a pro-development Australian government, as well as the establishment of long-term international contracts for the mine products. Exploration, drilling and construction began in 1964, and mining itself commenced in 1972 (Oliver 1991), despite objections from Bougainvilleans (O'Callaghan 2002). The ore body measured about 1 kilometre wide, 1.5 kilometres long and 600 metres deep, and the mine produced millions of tonnes of copper, hundreds of thousands of kilograms of gold and silver, hundreds of millions of kina in taxes and royalties to the PNG government, about 75 million kina in royalties to the North Solomons Province, and 22 million kina in royalties to landowners (Oliver 1991), although the latter royalties were inequitably spread among landowners with primary and secondary land rights (Wesley-Smith and Ogan 1992). The mine provided thousands of jobs, and the mining company provided largescale training and scholarships (Wesley-Smith and Ogan 1992). However, it also brought widespread social changes (Wesley-Smith and Ogan 1992) and environmental damage (Miriori 2002). The principles of land use employed by the mining company were foreign to Bougainvilleans (Ogan 1999; O'Callaghan 2002), and the mine's operations were the result of legal agreements in which Bougainvilleans had little or no say (Ogan 1999).

In addition to the mine, further context for the years prior to the Bougainville crisis is given by the issue of independence. Ogan (1990) found requests by Bougainville to be administered by the United 
States rather than Australia as early as the 1960s. The Hahalis movement in Buka in the 1960s formed in part as a protest against paying colonial taxes, while the Mungkas Association, comprised of Bougainvillean students at UPNG, produced a declaration in 1968 requesting the Australian administration to let Bougainville 'go it alone' (Havini 1990:20). Napidakoe Navitu Association held a referendum in 1971 that they claimed showed that almost 100 per cent of the sample supported independence, while in the same year Paul Lapun, who was involved in the formation of Napidakoe Navitu (Ogan 1999), presented a motion to the PNG House of Assembly for a referendum on Bougainville, but the colonial administration opposed it and it was defeated. The Pangu Pati also proposed a motion to investigate Bougainvilleans' feelings towards the issue but it was also defeated (Havini 1990).

In 1972, the PNG Constitutional Planning Committee examined ways of incorporating Bougainvillean aspirations for independence, leading to the formation of a provincial government system within Papua New Guinea (Ghai and Regan 2002). The deaths of two Bougainvilleans in Papua New Guinea helped to consolidate the independence movement and resulted in the formation of a Bougainville Special Political Committee (Havini 1990; Ghai and Regan 2002). However, negotiations between the Bougainvilleans and the PNG government strained over the issue of financial powers for the province and the perception among Bougainvilleans that there were unacceptable imbalances between national and provincial power and a lack of accountability in the proposals (Havini 1990:22; Ghai and Regan 2002). This led to a unilateral declaration of independence of the Republic of North Solomons on 1 September 1975, sixteen days before Papua New Guinea was due to become independent from Australia (Ghai and Regan 2002; Kabutaulaka 1994). The PNG government suspended the Bougainville provincial government, and, after a year, the Bougainvilleans accepted PNG sovereignty, having gained 'more substantial financial and legislative powers' (Havini 1990:24; Ghai and Regan 2002).

The war in Bougainville had a number of inter-related causes, including a dispute among landholders about royalty payments and 
concerns about the environmental and social impact of the mine (Claxton 1998; McMillan 1998; Miriori 2002; Ogan 1990; Ona 1990; Regan 1998), as well as the failure of the PNG government and Bougainville Copper Limited to undertake an agreed renegotiation of the mining agreement (Forster 1992). The dispute initially resulted in sabotage against the mine and its associated infrastructure. In response to this sabotage, the PNG government sent in the police riot squad and later the Papua New Guinea Defence Force (PNGDF) to quell the 'criminal' behaviour and protect the nation's economic interests in the mine (Dinnen 1999; Layton, 1992; Namaliu 1990). However, the heavy-handed tactics of these security forces and their abuses of human rights rallied many Bougainvilleans to the side of the rebels, in the form of the Bougainville Revolutionary Army (BRA), and expanded the dispute beyond the issues directly related to the mine (Kabutaulaka 1994; Layton 1992; May 2001; Miriori 2002; Ogan 1990). As a result, older issues, such as autonomy and independence for Bougainville, re-emerged (Ghai and Regan 2002; Hannett 1975; Havini 1990; Ogan 1990, 1999). Mounting casualties and disputes among PNGDF commanders about how to pursue the conflict led to the withdrawal of all PNGDF forces from Bougainville in 1990 (Oliver 1992; Sohia 2002). In addition, many public services and private enterprises, such as banks, withdrew from the province in 1990 as the violence increased (Sohia 2002). Further hardship occurred as the PNG government imposed an economic and communications embargo in mid 1990, resulting in a severe lack of medicine, food and fuel in the BRA controlled areas (Sohia 2002).

Left to rule the province, the BRA commanders and their newly formed civilian government, the Bougainville Interim Government (BIG), had difficulty controlling the BRA's various factions (McMillan 1998; Regan 1998). Violence against Bougainvilleans considered too closely aligned to the PNG government-as, for example, when young people from Inus and Tinputz in north Bougainville Island burnt Ieta village, near Buka (Regan 1998)_resulted in some disaffection with the BRA and the BIG (Regan 1998).

Some areas invited the PNGDF and government services to return, and some groups set up resistance forces to fight the BRA (O'Callaghan 
2002; Regan 1998; Sohia 2002). In particular, in September 1990, the PNGDF returned to Buka, where Leitana Nehan began its work. The PNGDF also took control of parts of the north and southwest of Bougainville Island in 1991-92, and, although abuses continued to occur, Regan (1998) argues that PNGDF was more disciplined in this second attempt to control the province.

Up to 50,000 people were placed in 'care centres' in PNGDFcontrolled areas, where abuses by the PNGDF were common (McMillan 1998; Saovana-Spriggs 2000). The naval blockade of the island, and particularly the areas controlled by the BRA, meant that essential services such as health and education were shut down, apparently leading to many deaths from diseases that would have been preventable with adequate medical supplies. ${ }^{1}$

Numerous attempts were made to resolve the conflict, with peace talks held on the HMNZS Endeavour in 1990, on the MV Huris in 1991, in Honiara in 1991 and 1994, at Arawa in 1994, and in Cairns in 1995 (Safu 1992; McMillan 1998; Sohia 2002). However, an effective truce was only signed as a result of two sets of talks at the Burnham army base in New Zealand in 1997 (Tapi 2002; Corry 2002). Several authors attribute the impetus for this truce to the change of PNG government caused by the Sandline crisis (see, for example, Regan 1998; O'Callaghan 2002). A permanent ceasefire was enacted following talks at Lincoln University in New Zealand in 1998 (Regan 1998). A peace agreement was signed in 2001 (Regan 2002a, 2002b), allowing for the disposal of weapons, the development of a constitution for an autonomous Bougainville, and elections for an autonomous government. In early 2005, the Bougainville Interim Provincial Government and the PNG government approved the constitution for an autonomous Bougainville, and elections were held in May-June 2005. At the time of writing, weapons disposal is complete in almost all areas of the province.

Peacekeeping and peace-building in Bougainville have had a number of dimensions. In terms of peacekeeping, the 1997 truce was monitored by a Truce Monitoring Group (TMG), led by New Zealand, and comprising unarmed peacekeepers from New Zealand, Australia, Fiji and Vanuatu. In 1998, the TMG was replaced with a Peace 
Monitoring Group, led by Australia. Its task was to facilitate the process of peace-building by monitoring the ceasefire and supervising the collection and containment of weapons (Regan 2001a, 2001b). In July 2003, the Bougainville Transitional Team replaced the PMG.

In terms of peace-building, diverse international actors such as AusAID and the Saika Grassroots Foundation have been responsible for providing funding for the re-establishment of infrastructure, such as new buildings at the Buka Open Campus of the University of Papua New Guinea (Ninnes et al. forthcoming), as well as the construction of roads and wharves. The Bougainville Provincial Government elected in 1999 has been responsible for re-establishing social institutions such as education, health and agriculture, and has worked with a wide range of local, national and international partners, such as governments in Australia, Japan and New Zealand, the PNG government and local churches. In terms of political institutions, autonomous Bougainville's constitution has been developed through a lengthy series of consultations both within Bougainville and with Papua New Guinea (Papua New Guinea Post Courier, 17 January 2005). Elections for an autonomous Bougainville government were held in May and June 2005.

Apart from Leitana Nehan, organisations such as the Bougainville Interchurch Women's Forum, the Bougainville Women for Peace and Freedom, the Catholic Women's Association, Bougainville Community-based Integrated Development Agency, Peace Foundation Melanesia, and The Bougainville Trauma Institute are providing a range of relevant services in areas such as critical literacy, reproductive health, small business management, counselling and community development (Böge and Garasu 2004; Garasu 2002; Howley 2003; Saovana-Spriggs 2003; Sirivi and Havini 2004). In addition, church leaders are playing a major role in working with people to undertake reconciliation and conceptualise a new peaceful vision for Bougainville (Fisher 2004). At the same time, many groups are engaging in reconciliation work using methods incorporating local cultural practices of symbolic weapons destruction, exchanges of gifts and religious ceremonies (Howley 2002, 2003; Saovana-Spriggs 2003). 
The remainder of this book has two major sections. The first section, comprising Chapters 2-5, describes and explains the history and work of the Leitana Nehan Women's Development Agency. Chapter 2 explores the early lives, schooling and community work of the four founders of Leitana Nehan, as well as the early work of the organisation from its founding in 1992 to its formal establishment in 1994. The chapter shows how the beliefs, values and experiences of life before and during the conflict created the impetus and motivation to form the organisation, how the founders' early work, focused mainly on humanitarian relief, raised their experience in gender-awareness and peace-building efforts and established their credibility in the community. In Chapter 3, we describe and analyse Leitana Nehan's works in its middle phase. During this period (199499), the organisation received numerous small grants from international non-government organisations and undertook a range of gender-awareness, peace-building and recovery projects. The chapter identifies the various factors that coalesced to allow the organisation to gain experience in all parts of the funding cycle and establish a track record in project management. The chapter also describes and analyses the political work of Leitana Nehan in terms of organising women and lobbying for peace. The purpose of Chapters 4 and 5 is to describe and explain Leitana Nehan's work in the period 2000-4. During this time, the organisation, in partnership with an Australian NGO, received major funding from an international aid agency for a program called 'Strengthening Communities for Peace'. The chapters describe how Leitana Nehan expanded its efforts to all the districts of Bougainville and recruited and trained teams of volunteers. In addition, the chapter describes and analyses other work undertaken by Leitana Nehan during this period, including education of civil society and government groups and political lobbying, and the impact these have had on communities in Bougainville.

The second section of the book, Chapters 6-8, analyses Leitana Nehan's work through a number of academic lenses. This part of the book is of particular interest to scholars in peace studies, development 
studies and Pacific island studies. In Chapter 6, Peter Ninnes employs post-structural theoretical frames to explore the ways in which Leitana Nehan has used various discourses of gender, development and peace. He shows the ways these discourses have changed over time to suit the local, regional and global circumstances, and traces the origins of these discourses to diverse sources. The analysis shows the ways in which members of a grassroots NGO have been able to learn and deploy key ideas at crucial moments. In Chapter 7, Jonathan Makuwira explores and analyses the partnerships that Leitana Nehan has entered into, especially the relationship between Leitana Nehan, the International Women's Development Agency (IWDA) and the Australian Agency for International Development (AusAID). The chapter examines the ways in which local and international partnerships contribute to peace-building and post-conflict recovery, and demonstrates the simultaneously complementary and contradictory terrain that global partnerships for peace and development need to negotiate. In Chapter 8, Peter Ninnes reviews Leitana Nehan's work in terms of peace-building, in terms of NGO practices, and in terms of the development of local, national and global networks.

The final chapter provides an epilogue by two of Leitana Nehan's founders, Helen Hakena and Agnes Titus, describing the work that has been done since the end of the Strengthening Communities for Peace project, and reflects on the impact of the work on communities and the volunteers who worked in them.

\section{NOTE}

1 The number of deaths attributed to the crisis range from 10,000 (Henderson 1999) to 12,000 (Bennett 2000) to 20,000 (Saovana-Spriggs 2000). 